\title{
THE NEUROMA-LIKE STRUCTURE OF THE LONG-TIME SEVERED AND ISOLATED NERVE STUMPS
}

\author{
Eros Abrantes Erhart * \\ CECIL J. RezZE**
}

Neuromas of the proximal stumps of transected nerves are know for a long time. They are due chiefly to the tremendous regenerative capacity of the injured peripheral neuron which axis-cylinders growing in a disorganized way result in a complex nervous nodule capped by fibrous tissue.

It is not our scope to discuss in this paper the neuromas, but report the presence of a neuroma-like structure we have mentioned in previous papers, while studying the nerve fibres of the long-time severed and experimentally isolated nerve stumps, Erhart and col.1, 2,3,4. Although we did not find any reference in literature about these neuroma-like structures, they were frequently found in our experimental material in the extremities of the repopulated intermediate and distal nerve segments, close to the site of section, and in some proximal extremities of distal stumps of human nerves which were examined at the time these patients were submitted to nerve suture years after the accidental nerve transection.

\section{MATERIAL AND METHODS}

As said before, the material which will be presented and discussed in this paper consists of the excised extremities of distal and intermediate stumps of fibular, intercostal, phrenic and ulnar nerves of dogs which were submitted to different experimental conditions of nerve transection as referred by or previous papers on this subject.

The stump extremities of the transected dog nervs and the tissues bridging the nerve segments were De Castro silver impregnated and serial sectioned $8 \mu$.

\section{RESULTS}

From the 40 experimental distal and for intermediate nerve stumps -8 fibular, 18 intercostal, 4 phrenic and 10 ulnar - maintained undisturbed in their surrounding connective bed for more than six months after complete nerve transection, in which the nerve fibre repopulation was evident, 26 presented in their extremities, close to the site of section, a neuroma-like structure.

Departamento de Anatomia da Faculdade de Medicina da Universidade de São Paulo (Prof. O. Machado de Sousa): * Professor Assistente, Docente-Livre, Chefe da Secçāo de Neuranatomia; ** Professor Assistente. 
In serial longitudinal and cross-sections of such stump extremities, moving from the stump to their extremity or extremities the following could be seen (fig. 1): The nerve fibres which were branching and repopulating the pattern nerve fascicles in the isolated stumps, after spreading off the nerve fascicles in a disorganized way, formed neuroma-like structures (figs. 1 and 2), from where sprouted few and diffuse nerve fibres which were capped by fibrous tissue, close to the site of section.

Several axis-cylinders showed the fusiform swellings considered as characteristic of regenerating nerve fibres.
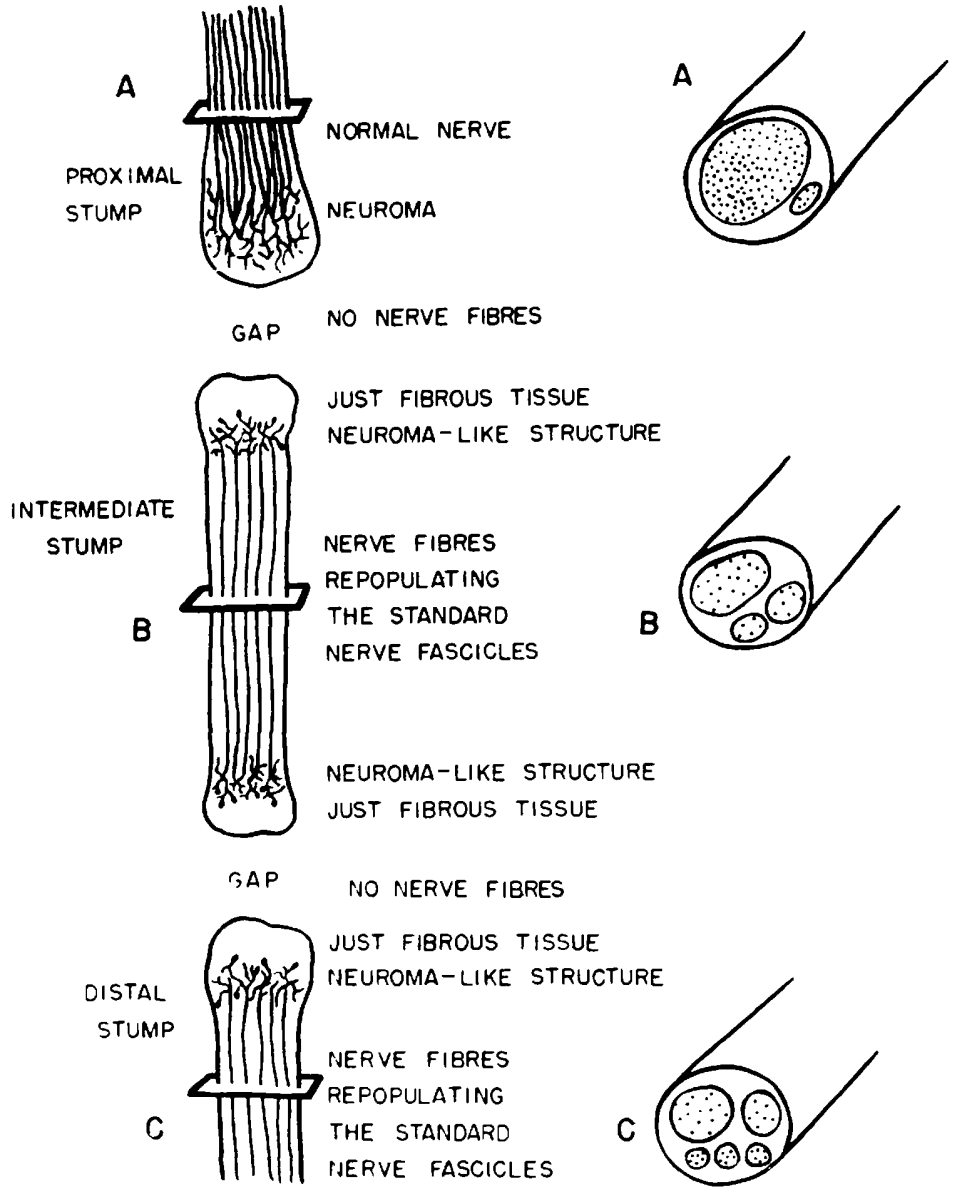

Fig. 1 - Scheme of nerve and neuroma-like structures one year after the double transection.

\section{DISCUSSION}

It has been generally accepted that long-time severed distal nerve segments degenerate completely and manifest changes considered inhibitory to subsequent regeneration; therefore, no neuroma-like structures could be expected 

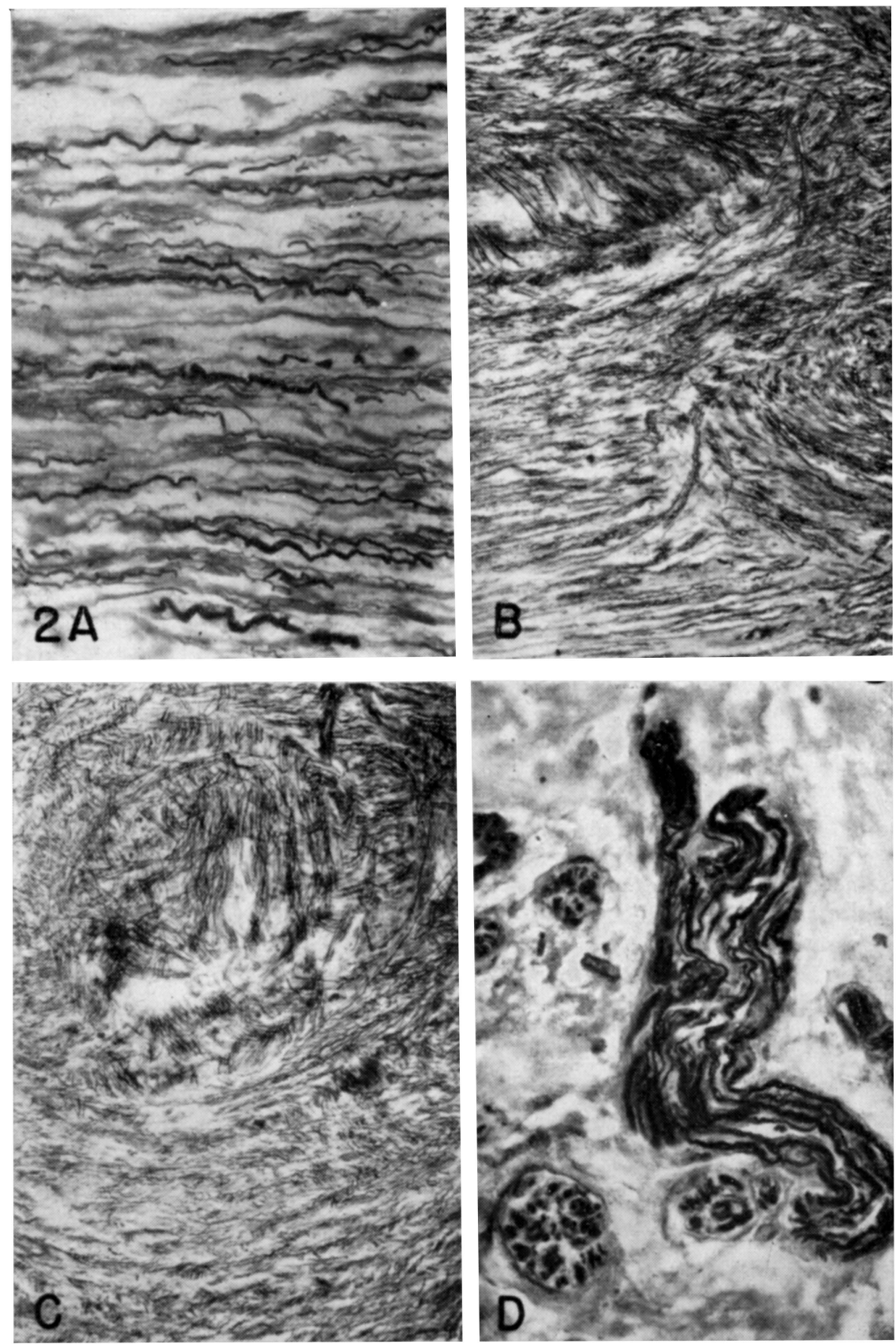

Fig. 2 - Photomicrographs of $8 \mu$ sections of nerves submitted to complete double transection. De Castro silver impregnation. A. Nerve fibres in the intermediate nerve stump completely separated from the proximal and distal stumps for one year $(\times 700)$. B. and C. Neuroma-like structures in distal and intermediate nerve segments extremities ( $\times 350)$. D. Neuroma-like structure capped by fibrous tissue $(\times 700)$. 
to be found in these stump extremities. But, our findings reported and discussed in previous papers, lead us to different conclusions.

Numerous nerve fibres which origin in still a matter of research and discussion, were seen branching and repopulating the long-time severed intermediate and distal nerve segments maintained undisturbed in their connective bed, although completely separated from each other and from the proximal stump. Several of these axis-cylinders showed beaded appearance and fusiform swellings in their extremities, characteristics of what has been considered as nerve fibres in regeneration. Therefore, the neuroma-like structures are probably the final result of a biological regenerative process equivalent to the one which originates the common neuromas. These latter as it is known, are formed by growing nerve fibres from the proximal stump; the former would be the result of growing nerve fibres proper of the intermediate and distal isolated nerve stumps.

\section{SUMMARY}

The long-time severed and isolated intermediate and distal nerve segments, maintained undisturbed in their connective tissue bed, completely separated from each other and from the proximal stump, are repopulated by nervefibres which origin is still unknown. The extremities of such nerve segments present complex nervous nodules capped by fibrous tissue, neuroma-like structures.

\section{RESUMO}

Segmentos intermédios e distais de nervos lesados há mais de seis meses, completamente separados entre si e do côto proximal, mas mantidos em seus respectivos leitos conetivos naturais, apresentam-se repopulados por fibras nervosas cuja origem é ainda motivo de discussão e pesquisa. Nas extremidades dêsses segmentos de nervos existem complexos nódulos, recobertos por tecido cicatricial, portanto, verdadeiras formaçōes neuromatosas.

\section{REFERENCES}

1. ERHART, E. A. - Normal nerve-fibres in the distal segment of nerves completely separated from the proximal stump for more than six months. Arq. NeuroPsiquiat. (São Paulo) 20:289-306, 1962. 2. ERHART, E. A. \& ERHART, M. B. Normal axis-cylinders in the distal segment of nerves completely separated from the proximal stump for up to 24 yers. Presented before the VII International Congress of Anatomists, New York, April 1960. Anat. Rec., 136:189, 1960. 3. ERHART, M. B. \& ERHART, E. A. - Sôbre o comportamento das fibras nervosas do côto distal de nervo fibular de Canis familiaris após transecção total. Presented before the III Meeting of the Soc. Brasileira de Anatomia, Porto Alegre, Oct. 1958 . Folia Clinica et Biologica (São Paulo) 28:98-100, 1958/59. 4. ERHART, E. A. \& REZZE, J. C. Nerve fibres in isolated segments of dog ulnar nerves after complete brachial plexotomy and periaxilar artery sympathectomy. Arq. Neuro-Psiquiat. (São Paulo) 23: 82-90, 1965.

Departamento de Anatomia. Faculdade de Medicina da Universidade de São Paulo - Caixa Postal 2921 - São Paulo, Brasil. 